\title{
A nova guerra contra o terror ${ }^{*}$
}

NOAM CHOMSKX

ODOS SABEM que são as televisões que mandam no mundo [risos da
platéia]. Acabo de receber ordens que devo me posicionar aqui, não lá.
Seja como for, a última palestra que proferi neste fórum tratou de um assunto leve e agradável. Falei sobre como os seres humanos são uma espécie ameaçada e, dada a natureza de nossas instituições, é provável que nos destruamos num tempo relativamente breve. Desta vez, temos um certo conforto e um assunto mais agradável, a nova guerra contra o terror. Infelizmente, o mundo não pára de aventar coisas que o tornam mais e mais terrível à medida que avançamos.

Vou pressupor duas condições nesta palestra.

A primeira, a meu ver, não é mais que o reconhecimento de um fato, a saber, que os eventos de 11 de setembro foram uma atrocidade hedionda. Fora da guerra, foi provavelmente a devastação com o maior número de vítimas instantâneas de qualquer crime na história.

O segundo pressuposto tem a ver com objetivos. Estou supondo que a nossa meta seja tentar reduzir a probabilidade de que tais crimes sejam cometidos - contra nós ou contra quem quer que seja.

Se não aceitarmos esses dois pressupostos, o que vou dizer não fará sentido. Se os aceitarmos, surgem de imediato algumas questões, intimamente relacionadas umas com as outras, que merecem profunda reflexão.

\section{As cinco questóes}

A primeira questão, de longe a mais importante, é: O que está acontecendo agora? Implícita nesta pergunta está outra: “O que poderemos fazer a respeito?" A segunda envolve a noção bastante prosaica de o que aconteceu em 11 de setembro ter sido um evento histórico, um acontecimento que irá mudar a história. Tendo a concordar com isso. Creio que seja verdade. Foi um evento histórico e a pergunta que deveríamos estar fazendo é precisamente: Por que? A terceira questão diz respeito ao título desta palestra, A guerra contra o terrorismo. Exatamente o que isso quer dizer? Com ela, vem uma pergunta associada: O que é terrorismo? A quarta, mais específica mas igualmente importante, tem a ver com as origens dos crimes de 11 de setembro. E a quinta questão que

* Palestra feita pelo autor em 18 de outubro de 2001 no Fórum de Tecnologia e Cultura do Massachusetts Institute of Technology (MIT), EUA. 
desejo abordar refere-se às políticas e ações de que dispomos para empreender essa guerra contra o terrorismo e lidar com as situações que levaram a ela.

Pretendo dizer algumas palavras a respeito de cada uma. Poderemos ir além delas em nossa discussão e não hesitem em levantar outras, se for o caso. Estas são as que me vêm à mente como mais proeminentes, mas pode haver outras igualmente plausíveis.

\section{O que está acontecendo agora?}

\section{Três a quatro milhões de pessoas irão morrer de fome}

Comecemos pelo presente imediato. Vou falar sobre a situação no Afeganistão. Pretendo me ater apenas a fontes não-controversas como The New York Times [risos da platéia]. De acordo com The New York Times, existem hoje no Afeganistão entre sete e oito milhões de pessoas no limiar da inanição. $\mathrm{Na}$ verdade, a situação precede 11 de setembro e essas pessoas só estavam sobrevivendo graças à ajuda internacional. No dia 16 de setembro, o Times noticiou - e eu cito - que os Estados Unidos exigiram que os paquistaneses pusessem fim aos comboios de caminhões que forneciam grande parte dos alimentos e suprimentos para a população civil do Afeganistão. Pelo que pude averiguar, não houve reação nos Estados Unidos - como também não houve reação na Europa. Eu estive em rádio nacional por toda a Europa no dia seguinte e, pelo que percebi, não houve reação alguma nos Estados Unidos ou na Europa à exigência de impor fome maciça a milhões de pessoas. A ameaça de ataques militares já forçara a remoção dos funcionários de agências internacionais, alijando os programas de ajuda humanitária. Estou mais uma vez citando The New York Times. Os refugiados que chegavam do Afeganistão ao Paquistão após árdua viagem descreviam cenas de desespero e medo em sua terra natal, à medida que a ameaça dos ataques liderados pelos Estados Unidos transformava a sua miséria de longa data numa catástrofe em potencial. De acordo com um funcionário evacuado, citado na New York Times Magazine, "o país só vinha sobrevivendo graças a uma corda salva-vidas” e agora nós cortamos essa corda.

O Programa Mundial de Alimentação das Nações Unidas, de longe o mais importante, pôde ser retomado três semanas depois, no início de outubro, ainda que em níveis mais baixos, e a remessa de alimentos foi parcialmente restabelecida. Mas não existem mais funcionários de agências humanitárias dentro do Afeganistão, de modo que o sistema de distribuição, que fora suspenso logo que os bombardeios começaram, está prejudicado. A ajuda internacional foi restabelecida, mas num ritmo bem mais lento, enquanto as agências humanitárias denunciavam com veemência que os pacotes de alimento lançados por avióes norte-americanos eram meros instrumentos de propaganda que provavelmente estavam fazendo mais mal do que bem. Estou agora citando o London Financial Times. Após a primeira semana de bombardeios, The New York Times 
noticiou numa página interna, no meio de uma coluna sobre outro assunto, que segundo cálculos das Nações Unidas haveria em breve 7,5 milhões de afegãos sofrendo necessidades desesperadoras, sem terem sequer pão para comer. Em algumas poucas semanas começaria o severo inverno afegão, tornando a entrega e distribuição de víveres praticamente impossível em muitas áreas. Além disso, e continuo citando, com bombas caindo em toda a parte, o ritmo das entregas caíra para metade do que seria necessário. Tudo isso num comentário informal.

Mas o fato é que a civilização ocidental está prevendo o massacre de - façamos as contas - três a quatro milhões de pessoas, ou algo parecido. No mesmo dia, o líder da civilização ocidental mais uma vez preteriu com desdém uma oferta para que fosse negociada a entrega do seu suposto alvo, Osama bin Laden, e também o pedido para que fosse apresentada alguma prova que corroborasse a exigência de capitulação total. Ambos foram relegados. Também no mesmo dia, o emissário especial das Nações Unidas encarregado da distribuição de alimentos implorou aos Estados Unidos que cessassem os bombardeios, para que tentassem salvar milhões de vítimas. Pelo que pude averiguar, o apelo não chegou a ser noticiado. Isso foi na segunda-feira. Ontem [quarta-feira], as principais agências humanitárias - Oxfam, Christian Aid, entre outras - juntaram-se ao apelo. Não encontramos menção alguma no The New York Times. O Boston Globe publicou uma linha, escondida numa reportagem sobre outro assunto, a Caxemira.

\section{Genocídio silencioso}

Poderíamos prosseguir facilmente. Tudo isso indica-nos o que está acontecendo. E o que está acontecendo parece ser uma espécie de genocídio silencioso. Essa realidade também nos proporciona um bom insight da cultura das elites, a cultura da qual somos parte. Pois não importa o que possa acontecer - e não sabemos o que vai acontecer - o fato é que planos estão sendo elaborados e programas sendo implementados a partir do pressuposto de que podem provocar a morte de milhões de pessoas nos próximos meses. Tudo muito informalmente, en passant, sem maiores reflexões a respeito. Tudo visto como algo normal e corriqueiro, tanto nos EUA como em grande parte da Europa, porém, não no resto do mundo. Na verdade, nem mesmo em muitos lugares da Europa. Se lermos jornais irlandeses ou escoceses, tão próximos, as reações já são bem diferentes.

Bem, é isso o que está acontecendo hoje. E o que está acontecendo hoje está perfeitamente sob nosso controle. Poderemos fazer muita coisa para afetar essa realidade. É basicamente isso. 


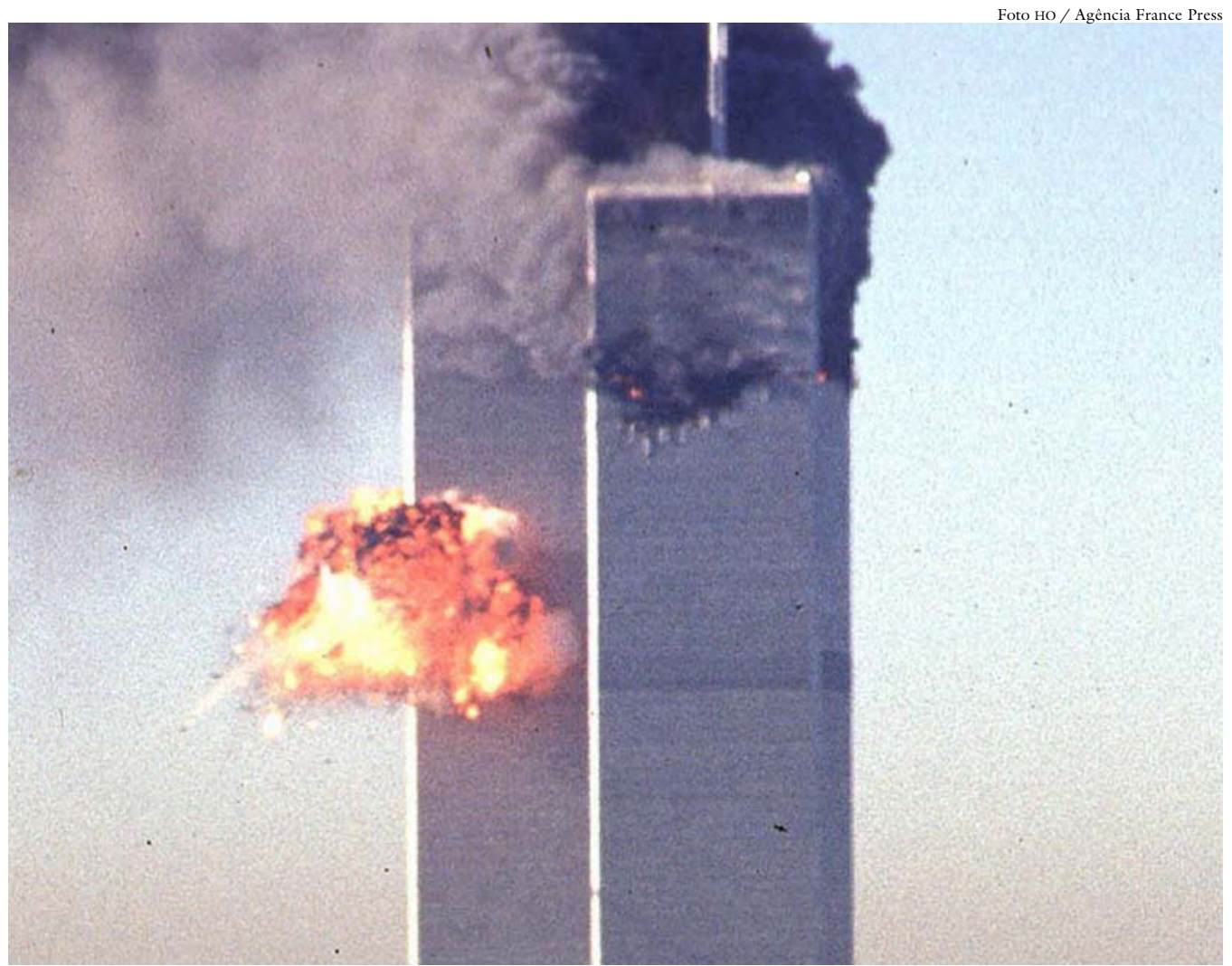

Às 10h06m, o segundo avião sequestrado atinge a outra torre do WTC em Nova York.

\section{Por que 11 de setembro foi um evento histórico? Ataque ao território nacional}

Pois bem, voltemo-nos agora a uma questão um pouco mais abstrata, esquecendo por uns instantes que estamos aparentemente prestes a matar três ou quatro milhões de pessoas - não do Taliban, é claro; suas vítimas. Recapitulemos. Os ataques de 11 de setembro foram um evento histórico? Como já disse, acredito que sim. Onze de setembro foi um evento histórico mas, lamentavelmente, não pelas dimensões da catástrofe. É desa-

... a direção

em que as armas estão apontadas mudou ...

gradável pensar nisso, mas

em termos de escala, os ataques não foram algo incomum - embora talvez seja verdade que nenhum outro crime da história tenha tido um número maior de vítimas humanas instantâneas. Infelizmente, porém, existem muitos outros crimes terroristas com efeitos mais duradouros e mais extremos. Não obstante, 11 de setembro foi um evento histórico, pois ocorreu uma mudança: a direção em que as armas estão apontadas mudou. E isso é algo novo, radicalmente novo. 


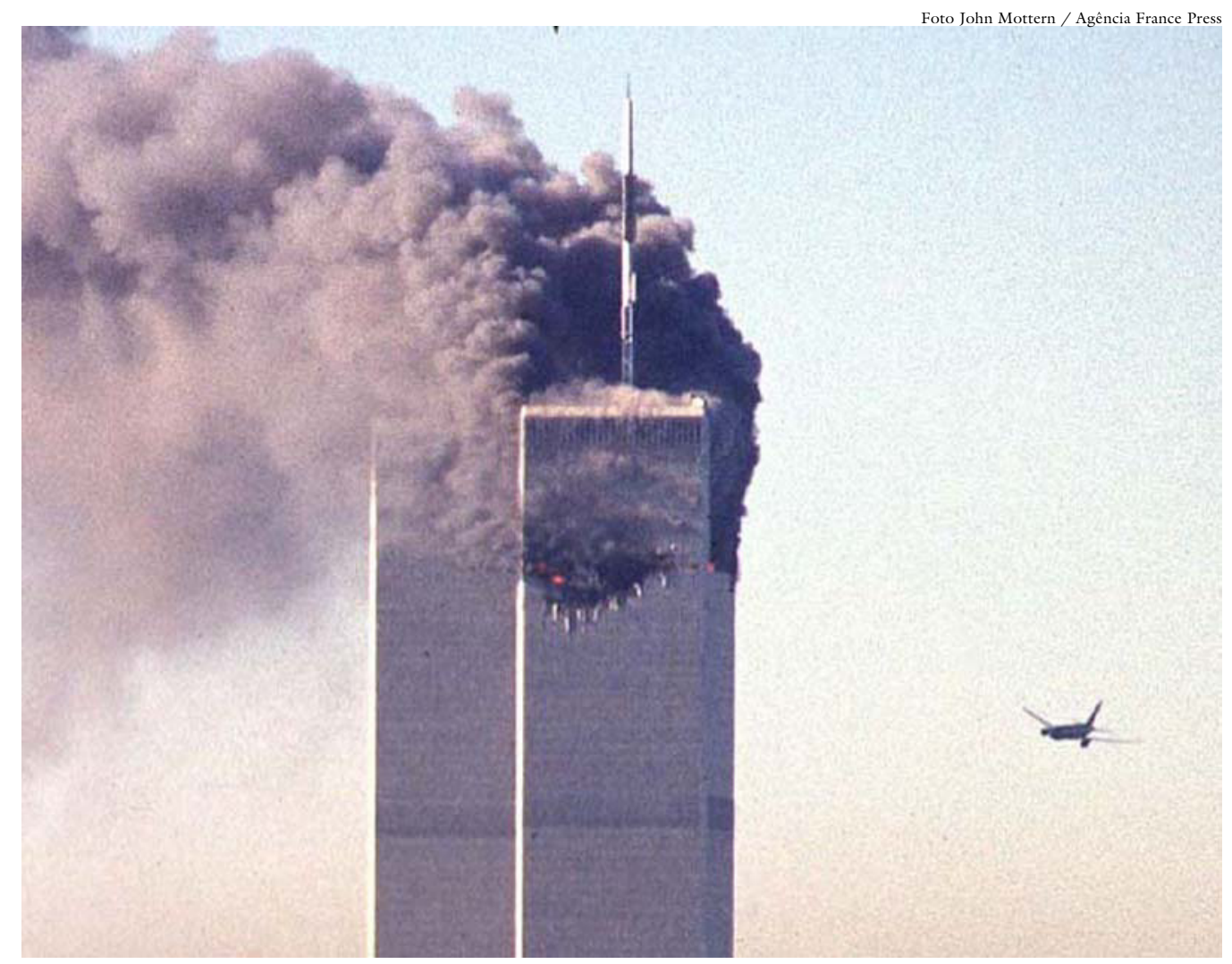

Às 9h48m, o primeiro avião atinge uma das torres do World Trade Center em Nova York.

Examinemos a história dos Estados Unidos. A última vez que o território nacional norte-americano esteve sob ataque, ou mesmo sob ameaça, foi quando os britânicos incendiaram Washington em 1814. Muitos mencionaram Pearl Harbor na ocasião, mas não é uma boa analogia. Os japoneses, não importa o que possamos pensar deles, bombardearam bases militares em duas colônias e não o território nacional dos Estados Unidos. Colônias que, por sinal, haviam sido tomadas de seus habitantes de maneira nada bonita. Desta vez, no entanto, o território nacional foi atacado em grande escala. É possível encontrar alguns outros exemplos menores, mas este foi um evento único.

Ao longo desses quase 200 anos, nós, os Estados Unidos, expulsamos ou exterminamos a população nativa - muitos milhões de pessoas -, conquistamos metade do México, provocamos depredações por toda a região, no Caribe e na América Central - às vezes mais longe ainda - e conquistamos o Havaí e as Filipinas (matando mais de 100 mil filipinos no processo). Desde a Segunda Guerra, o país estendeu seu alcance ao redor do mundo de maneiras que não preciso descrever. Mas sempre envolveram matar alguém. Sempre envolveram lutar em algum outro lugar. Sempre foram outros os massacrados. Nunca aqui. Nunca o território nacional. 


\section{Europa}

No caso da Europa, a mudança foi mais drástica, pois a história européia é ainda mais horrenda que a norte-americana. Nós somos uma mera ramificação da Europa, basicamente. Há centenas de anos, a Europa vem corriqueiramente massacrando pessoas em todo o planeta. Foi assim que conquistaram o mundo, não oferecendo docinhos para bebês. Ao longo dos séculos, a Europa realmente passou por várias guerras mortíferas, mas essas guerras sempre envolveram matadores europeus matando outros europeus. Durante muito tempo, o

... a história européia é ainda mais horrenda que a norte-americana ... principal esporte europeu foi massacrarem-se uns aos outros. O motivo de isso ter chegado ao fim em 1945 não teve nada a ver com a democracia ou com o fato de a noção de guerrear entre si ter saído de moda. O único motivo foi todos terem compreendido que da próxima vez que quisessem entrar nesse jogo seria o fim do mundo. Pois, como nós, os europeus haviam desenvolvido armas de destruição tão terríveis que a brincadeira tinha de acabar. Seja como for, essa história remonta a centenas de anos. No século XVII, cerca $40 \%$ da população da Alemanha foi provavelmente eliminada em guerras.

Entretanto, durante todo esse longo período sangüinolento, o que víamos eram europeus trucidando-se uns aos outros e também europeus trucidando pessoas fora da Europa. O Congo não atacou a Bélgica, a Índia não ata-

\section{... o que víamos \\ eram europeus trucidando-se \\ uns aos outros ...} cou a Inglaterra, a Argélia não atacou a França. Isso foi uniforme. Houve, por certo, algumas pequenas exceções, mas de escala diminuta, quase invisíveis diante das dimensões do que a Europa e os Estados Unidos fizeram com o resto do mundo. Esta foi a primeira mudança: pela primeira vez, as armas foram apontadas na outra direção. Na minha opinião, é provavelmente por isso que encontramos reações tão diferentes de um e outro lado do mar da Irlanda - como pude observar em entrevistas e em rádios nacionais de lá e de cá. O mundo parece muito diferente dependendo de quem está segurando o chicote e de quem está levando chibatadas há séculos. Muito diferente. Por isso acho que o choque e a surpresa na Europa e em suas ramificações, como nós aqui, são bastante compreensíveis. Onze de setembro foi um evento histórico, lamentavelmente não em termos de escala, mas sim em algo mais. É por isso que a maior parte do resto do mundo encara os fatos de maneira bem diferente: não sem comiseração pelas vítimas da atrocidade, não sem horror diante do que aconteceu - isso é quase uniforme. Mas a perspectiva é diferente. E isso é algo que faríamos bem em tentar compreender. 


\section{O que é a guerra contra o terrorismo? O que é terrorismo?}

Passemos então à terceira questão: O que é a guerra contra o terrorismo? E à pergunta a ela associada: O que é terrorismo? A guerra contra o terrorismo já foi descrita em altos escalões como a luta contra uma praga, contra um câncer disseminado por bárbaros, por "opositores depravados da própria civilização". É um sentimento do qual partilho. As palavras que estou citando, no entanto, foram proferidas 20 anos atrás pelo presidente Reagan e seu secretário de Estado. Há 20 anos, o governo Reagan assumiu o poder declarando que a guerra contra o terrorismo internacional seria o cerne da política externa norte-americana e descreveu-a nos termos que acabei de mencionar. De fato, essa guerra foi o cerne da nossa política exterior. Curiosamente, o governo Reagan reagiu à praga do terror, "disseminada por opositores depravados da própria civilização", criando uma extraordinária rede terrorista internacional, de abrangência inaudita, que levou a cabo incontáveis atrocidades em todo o mundo.

\section{Reagan: a guerra dos Estados Unidos contra a Nicarágua}

Mencionarei apenas um caso, um caso totalmente incontroverso, a fim de evitar qualquer dúvida ou discussão a respeito. Não é, em absoluto, o caso mais extremo. Mas é incontroverso, pois foi julgado pelas maiores autoridades internacionais: o Tribunal Internacional de Justiça, a Corte Mundial e o Conselho de Segurança das Nações Unidas. Insisto: este caso é incontroverso, pelo menos entre pessoas minimamente preocupadas com leis internacionais, direitos humanos, justiça e temas afins.

Gostaria de passar-lhes um exercício. Quero que calculem as dimensões desse episódio perguntando-se com que freqüência o caso foi mencionado nas notícias e editoriais do mês passado. Este caso é particularmente relevante, não só por ser incontroverso, mas também porque constituiu um precedente de como um Estado cumpridor das leis reagiria, e de fato reagiu, ao terrorismo internacional. A situação foi ainda mais extrema do que os acontecimentos de 11 de setembro. Estou me referindo à guerra de Reagan e dos Estados Unidos contra a Nicarágua, que deixou dezenas de milhares de mortos e o país em ruínas - talvez irrecuperavelmente.

\section{A reação da Nicarágua}

A Nicarágua reagiu. Mas não lançando bombas em Washington. Reagiu levando o caso à Corte Mundial e apresentando uma demanda. Não tiveram problema algum em reunir provas. A Corte Mundial aceitou julgar o caso, sentenciou em favor da Nicarágua, condenou o que chamou de "uso ilegítimo da força" - um outro termo para terrorismo internacional - por parte dos Estados Unidos e ordenou que os norte-americanos cessassem o seu crime e inde- 
nizassem os nicaraguenses. Os Estados Unidos, é claro, relegaram a sentença do tribunal ao absoluto desprezo e anunciaram que doravante não aceitariam mais a jurisdição dessa corte.

A Nicarágua procurou então o Conselho de Segurança das Nações Unidas, que considerou uma resolução conclamando todos os Estados a respeitarem o direito internacional. Ninguém foi mencionado, mas todos compreenderam. Os Estados Unidos vetaram a resolução e são hoje a única nação que, ao mesmo tempo, foi condenada por praticar terrorismo internacional pela Corte Mundial e vetou uma resolução do Conselho de Segurança convocando os Estados a respeitarem o direito internacional.

A Nicarágua dirigiu-se então à Assembléia Geral, na qual tecnicamente não existe o veto mas onde um voto negativo dos Estados Unidos equivale a um veto. A Assembléia Geral aprovou uma resolução similar, com oposição apenas dos Estados Unidos, de Israel e de El Salvador. No ano seguinte aconteceu a mesma coisa, mas dessa vez os Estados Unidos só conseguiram arregimentar Israel para a causa, de modo que houve apenas dois votos contra o respeito ao direito internacional. Diante disso, não restou outra saída lícita para a Nicarágua. Ela tentara todas as medidas, mas nada funcionou num mundo que é regido pela força.

Embora este caso seja incontroverso, não é, em absoluto, o mais extremo. Adquirimos uma curiosa percepção da nossa própria cultura e sociedade, e do que está acontecendo hoje, perguntando: Quanto sabemos sobre tudo isso? Quanto conversamos a respeito? Quanto aprendemos sobre isso na escola? Quanto disso está nas manchetes dos jornais? E isso é apenas o começo.

Os Estados Unidos reagiram à Corte Mundial e ao Conselho de Segurança ampliando incontinenti a guerra - uma decisão bipartidária, diga-se de passagem. E os termos da guerra também mudaram. Pela primeira vez, foram dadas ordens oficiais para que o exército terrorista atacasse os chamados soft targets (alvos brandos), isto é, alvos civis indefesos, e evitasse confrontar o exército nicaragüense. Puderam fazer isso porque os Estados Unidos tinham controle total do espaço aéreo sobre a Nicarágua e o exército mercenário fora suprido com equipamentos avançados de comunicação. Não era um exército guerrilheiro no sentido normal, pois podiam receber instruções sobre a disposição das forças do exército nicaragüense e, com isso, atacar fazendas coletivas, clínicas de saúde e outros soft targets com impunidade. Estas eram as ordens oficiais.

\section{Qual foi a reação nos Estados Unidos ?}

Houve uma reação, talvez a esperada. A política norte-americana foi considerada "sensata" pela opinião liberal de esquerda. Assim, Michael Kinsley, que representa a posição "oficial" da esquerda, escreveu um artigo afirmando que não deveríamos condenar de imediato essa política, como a Human Rights 
Watch fizera. Ele disse que uma "política sensata" deve "passar pelo teste da análise do custo/benefício" - ou seja, e estou citando agora, uma análise "da quantidade de sangue e desgraça que será infligida e da probabilidade de que uma democracia possa emergir na outra extremidade" - democracia conforme os Estados Unidos entendem o termo, ilustrada de maneira vívida nos países vizinhos.

Observem como é axiomático que os Estados Unidos, as elites norteamericanas, têm o direito de conduzir a análise e de levar o projeto adiante se ele passar nos seus testes - como de fato passou. O projeto funcionou. Quando a Nicarágua finalmente sucumbiu ao ataque da superpotência, comentaristas saudaram abertamente o sucesso dos métodos adotados, descrevendo-os com precisão. Citarei apenas a revista Time, que louvou o sucesso dos métodos adotados: "Arruinar a economia e empreender uma longa e mortífera guerra 'por procuração' até que os nativos, exauridos, consigam derrubar eles próprios o governo indesejável”, a um custo "mínimo" para nós, deixando às vítimas o legado de "pontes destruídas, usinas elétricas sabotadas e fazendas arruinadas" e fornecendo ao candidato norte-americano um tema capaz de conduzi-lo à vitória: "pôr fim ao empobrecimento do povo da Nicarágua". The New York Times publicou uma manchete que exclamava: "Americanos Unidos em Júbilo" diante do resultado.

\section{O terrorismo funciona. \\ O terrorismo não é a arma dos fracos}

Esta é a cultura em que vivemos e ela nos revela muitas coisas. A primeira é que o terrorismo funciona. $\mathrm{O}$ terrorismo não é malsucedido. Ele dá certo. A violência geralmente funciona. Essa é a história do mundo. A segunda é que é um gravíssimo erro analítico dizer, como se costuma fazer, que o terrorismo é a arma dos fracos. Como qualquer outro meio de violência, o terrorismo é primordialmente, esmagadoramente, uma arma dos fortes. É considerado a arma dos fracos porque os fortes também controlam os sistemas doutrinários, nos quais o seu terror não conta como terror. Isso é algo quase universal. Não consigo pensar em uma única exceção histórica; até os piores assassinos em massa vêem o mundo assim.

Vejamos os nazistas. Eles não estavam praticando terror na Europa ocupada; estavam protegendo as populações locais do terrorismo dos sectários. Ora, como em qualquer outro movimento de resistência, havia terrorismo. Os nazistas, portanto, estariam praticando contraterrorismo. Em essência, os Estados Unidos concordaram. Após a guerra, o exército norte-americano realizou demorados estudos sobre as operações nazistas de contraterrorismo na Europa. Mas antes devo dizer que os Estados Unidos adotaram e começaram eles próprios a pôr em prática esse tipo de operação, muitas vezes contra os mesmos alvos, a antiga resistência. Além disso, nossos militares também estudaram os 
métodos nazistas e chegaram a publicar estudos interessantes, alguns deles criticando o modo ineficiente como as operações foram realizadas - uma análise crítica, portanto: vocês fizeram isso certo, vocês fizeram isso errado. Esses métodos, com a assessoria dos oficiais da Wermacht trazidos para os Estados Unidos, iriam se transformar nos manuais de contrainsurgência, de contraterrorismo, de "conflitos de baixa intensidade", como são chamados. São esses os manuais e procedimentos que usamos hoje.

Portanto, a questão não é apenas que os nazistas agiram assim, mas também que essa foi considerada a maneira certa de agir pelos líderes da civilização ocidental - ou seja, nós - que então procederam para fazer a mesma coisa. O terrorismo não é a arma dos fracos. É a arma daqueles que estão contra "nós", não importa quem seja esse "nós". Se alguém conseguir encontrar uma exceção história a isso, eu estaria muito interessado em conhecê-la.

\section{A natureza da nossa cultura: como nós encaramos o terrorismo}

Uma indicação interessante da natureza da nossa cultura, da nossa alta cultura, é o modo como encaramos isso. Nossa primeira reação é suprimir tudo, ou seja, praticamente ninguém ouve falar dessas coisas. E o poder da propaganda e da doutrina norte-americanas é tamanho que mesmo entre as vítimas a realidade mal é conhecida. Quero dizer, se conversarmos sobre isso com alguém da Argentina, teremos de lembrá-lo: "Ah, sim, isso aconteceu. Tinha me esquecido". Tudo é profundamente suprimido. As conseqüências do monopólio da violência podem ser muito poderosas, seja em termos ideológicos ou não.

\section{A idéia de que a Nicarágua poderia, talvez, ter o diveito de se defender}

Um aspecto esclarecedor da nossa atitude perante o terrorismo é a reação à idéia de que a Nicarágua poderia, talvez, ter o direito de se defender. Pesquisei isso razoavelmente a fundo em bases de dados. A idéia de que a Nicarágua poderia ter o direito de se defender era considerada uma afronta, um absurdo. Não há praticamente nada entre os observadores da mídia oficial que indique que a Nicarágua poderia ter esse direito. Este fato foi explorado pelo governo Reagan e sua máquina de propaganda de uma maneira interessante. Quem viveu isso haverá de lembrar que periodicamente eram lançados rumores de que os nicaragüenses estariam recebendo aviões a jato MIG - jatos da Rússia. Neste ponto, os gaviões e as pombas dividiam-se. Os gaviões diziam: "Ok, então vamos lá bombardeá-los". As pombas diziam: "Esperem um pouco, vamos ver se os rumores são verdadeiros. Caso sejam, então vamos lá bombardeálos. Pois são uma ameaça aos Estados Unidos."

Por falar nisso, por que os nicaragüenses estavam obtendo MIGs? Bem, eles haviam tentado obter jatos de países europeus, mas os Estados Unidos 
pressionaram seus aliados para que não thes enviassem meios de defesa, pois "queríamos" que eles recorressem aos russos. Isso era bom para fins de propaganda: foi assim que os nicaragüenses se tornaram uma ameaça para nós. Lembrem-se que estavam a apenas dois dias de caminhada de Harlingen, Texas. Nós chegamos até a declarar emergência nacional em 1985 para proteger o país da ameaça da Nicarágua. De modo que era muito melhor que obtivessem armas dos russos.

E por que os nicaragüenses haveriam de querer aviões a jato? Bem, pelos motivos já mencionados. Os Estados Unidos tinham controle total de seu espaço aéreo, sobrevoavam-no constantemente e usavam isso para fornecer informações para o exército terrorista atacar os soft targets sem precisar enfrentar $\mathrm{o}$ exército nacional, que talvez tentasse defender aqueles alvos. Todos sabiam que este era o motivo. Eles não iam usar os aviões a jato para nada mais. Mas a idéia de que à Nicarágua fosse permitido defender seu espaço aéreo contra um ataque da superpotência, que estava direcionando as forças terroristas a atacarem alvos civis indefesos, era considerada uma afronta aos Estados Unidos - unanimemente. As exceções foram tão poucas que eu poderia até dar-lhes uma lista. Mas não estou sugerindo que acreditem em mim. Façam uma pesquisa. Essa unanimidade incluiu até nossos próprios senadores, por falar nisso.

\section{Honduras: a nomeação de Jobn Negroponte como embaixador nas Naçôes Unidas}

Uma outra ilustração do modo como encaramos o terrorismo pode ser observada neste exato momento. Há cerca de duas semanas, os Estados Unidos nomearam um embaixador para as Nações Unidos para comandar a guerra contra o terrorismo. Pois bem, quem é ele? Seu nome é John Negroponte. Ele foi o embaixador norte-americano no feudo - pois é isso que é - de Honduras no início dos anos 80 . Houve um certo rebuliço, pois Negroponte deveria conhecer - e certamente conhecia - os assassinatos em massa e outras atrocidades cometidas na época pelas forças de segurança que apoiávamos em Honduras. Mas isso é apenas uma pequena parte. Como procônsul, como era chamado lá, $\mathrm{Ne}$ groponte foi o responsável local pela guerra terrorista empreendida contra a Nicarágua a partir de Honduras, pela qual o seu governo foi condenado pela Corte Mundial e pelo Conselho de Segurança. A despeito disso, Negroponte acaba de ser nomeado embaixador nas Nações Unidas para liderar a guerra contra o terror. Outro pequeno experimento que podemos fazer é tentar descobrir qual foi a reação a isso. Eu poderia lhes adiantar o que vão descobrir, mas descubram por si mesmos. É algo que diz muito sobre a guerra contra o terrorismo e sobre nós mesmos.

Depois que os Estados Unidos assumiram o controle outra vez, sob condições tão vividamente descritas pela imprensa, o país foi basicamente destruído nos anos 80. Desde então, entrou em colapso total em praticamente todos os 
aspectos. Em termos econômicos, o declínio foi tremendo; quanto à democracia... Hoje é o segundo país mais pobre do hemisfério. Bem, nem vou falar a respeito. Eu escolhi a Nicarágua porque era um caso incontroverso. Mas se observarmos as outras nações da região, veremos que o terror estatal foi muito mais extremo e sempre pode ser traçado até Washington. E isso não é tudo, de maneira alguma.

\section{Apoio dos Estados Unidos e do Reino Unido aos ataques da África do Sul}

O mesmo estava acontecendo em outras partes do mundo, como na África. Apenas durante os anos Reagan, os ataques da África do Sul a países vizinhos, com apoio e suporte dos Estados Unidos e do Reino Unido, mataram mais de 1,5 milhão de pessoas, causaram mais de US\$ 60 bilhões de danos e destruíram países inteiros. Se dermos a volta ao mundo acrescentaremos muitos outros exemplos.

Essa foi a primeira guerra contra o terror, da qual apresentei uma pequena amostra. Será que não deveríamos dar atenção a ela? Ou pelo menos achar que, talvez, ela seja relevante? Afinal de contas, não se trata exatamente de história antiga. Mas a resposta é claramente negativa se nos basearmos no debate atual sobre a guerra contra o terror, que tem sido o tema principal das discussões no último mês.

\section{Haiti, Guatemala e Nicarágua}

Como mencionei, a Nicarágua tornou-se o segundo país mais pobre do hemisfério. Qual é o mais pobre? O Haiti, é claro - que também foi, de longe, a maior vítima das intervenções norte-americanas no século XX. Nós deixamos o país totalmente devastado. O Haiti é o país mais pobre. E a Nicarágua vem em segundo lugar, também no grau de intervenção norte-americana no século $\mathrm{XX}$. É o segundo país mais pobre. Na realidade, está competindo com a Guatemala pela posição. A cada um ou dois anos, Nicarágua e Guatemala se alternam como segundo país mais pobre. E também se alternam em ser o principal alvo da intervenção militar norte-americana. Será que devemos supor que tudo isso é alguma espécie de acidente, não tendo nada a ver com o que aconteceu ao longo da história? Talvez.

\section{Colômbia e Turquia}

O pior violador dos direitos humanos nos anos 90 foi, de longe, a Colômbia. A Colômbia foi também o país que mais recebeu auxílio militar norteamericano naquela década, mantendo o terror e as violações aos direitos humanos. Em 1999, a Colômbia tomou o lugar da Turquia como o país que mais recebeu armamentos norte-americanos - isto é, excluindo Israel e Egito, que estão numa categoria à parte. Isso também nos diz muito sobre a atual guerra ao terror. 
Por que a Turquia recebeu um fluxo tão maciço de armas norte-americanas? Bem, se examinarmos o fluxo dos armamentos, veremos que a Turquia sempre obteve muitas armas dos Estados Unidos. Para começar, o país tem uma localização estratégica e é membro da OTAN. Mas o fluxo de armas para a Turquia aumentou perceptivelmente em 1984. Isso nada teve a ver com a Guerra Fria, pois a Rússia já estava desmoronando. O fluxo permaneceu elevado de 1984 a 1999, quando foi reduzido e a Colômbia assumiu a liderança. O que aconteceu de 1984 a 1999 ?

Em 1984, a Turquia lançou uma grande guerra terrorista contra os curdos no sudeste do país, justamente quando a ajuda norte-americana, a ajuda militar norte-americana, se intensificou. E não estamos falando de meras pistolas, mas sim de aviões a jato, tanques, treinamento militar e coisas do gênero. Essa ajuda permaneceu elevada durante toda a escalada de atrocidades nos anos 90. A ajuda aumentava à medida em que as atrocidades aumentavam. O pico foi em 1997, quando a ajuda militar dos Estados Unidos foi maior do que durante todo o período entre 1950 e 1983, ou seja, durante a época da Guerra Fria - o que é indicativo do quanto a Guerra Fria afetou as diretrizes do país. Os resultados foram aterradores: entre dois e três milhões de refugiados, um dos piores extermínios étnicos do final dos anos 90. Dezenas de milhares de pessoas foram mortas, 3.500 cidades e vilas destruídas, muito mais do que no Kosovo, mesmo com as bombas da OTAN.

E os Estados Unidos estavam fornecendo $80 \%$ das armas usadas pela Turquia, um fluxo que aumentava à medida que as atrocidades aumentavam, até $\mathrm{o}$ pico de 1997. Houve uma diminuição em 1999, pois o terror já havia cumprido sua função - como geralmente acontece quando perpetrado por seus principais agentes, os poderosos. Assim, em 1999 o terror turco - designado contraterror, evidentemente, mas como já disse, isso é universal - mostrou que funcionara. A Turquia foi então substituída pela Colômbia, que ainda não tivera sucesso na "sua" guerra terrorista e que, portanto, precisava tornar-se a principal recipiendária de armas norte-americanas.

\section{Autocongratulações da parte dos intelectuais ocidentais}

O que torna tudo isso particularmente chocante é que ocorreu em meio a um tremendo estardalhaço autocongratulatório da parte dos intelectuais do Ocidente, algo provavelmente sem paralelo na história. Todos devem se lembrar, não faz mais do que dois ou três anos. Foi uma tremenda onda de autoadulação em torno de como, pela primeira vez na história, havíamos sido realmente magnificentes - defendendo princípios e valores, dedicando-nos a pôr um fim à desumanidade em todo lugar na nova era, e mais isso e mais aquilo. "Por certo, não podemos tolerar atrocidades tão próximas das fronteiras da OTAN". Isso foi repetido incessantemente. Somente dentro das fronteiras da OTAN poderemos não só tolerar atrocidades muito piores, mas até contribuir para elas. 
Se perguntarmos com que freqüência isso foi trazido à tona, teremos mais um vislumbre da civilização ocidental e da nossa própria. Investiguem isso. Não vou repetir. É algo muito instrutivo, um feito bastante impressionante para um sistema de propaganda numa sociedade livre. É espantoso. Acho que nem mesmo num Estado totalitário isso seria possível.

\section{A Turquia ficon muito agradecida}

A Turquia ficou muito agradecida e há poucos dias, o primeiro-ministro Ecevit anunciou que seu país se juntaria à coalizão contra o terror - com grande entusiasmo, com até mais entusiasmo que os outros. Na verdade, ele disse que a Turquia participaria da coalizão com tropas, algo que outros países não se dispuseram a fazer. E explicou: "Temos uma dívida de gratidão com os Estados Unidos, pois os Estados Unidos foram o único país que se dispôs a contribuir tão maciçamente para a nossa guerra contraterrorista" - estas foram as suas palavras. Ou seja, contribuir para o extermínio étnico com atrocidades e terror. Outros países ajudaram um pouco, mas se refrearam.

Os Estados Unidos, por outro lado, contribuíram com entusiasmo e impetuosidade. E puderam fazê-lo por causa do silêncio - subserviência seria a palavra certa - das classes instruídas, que poderiam facilmente ter se mantido informadas de tudo. Afinal, este é um país livre. Podemos ler relatórios sobre direitos humanos. Podemos ler sobre qualquer coisa. Mas optamos por contribuir para as atrocidades. A Turquia está muito feliz com isso, sente que tem uma dívida de gratidão conosco e, portanto, contribuirá com tropas, como ocorreu durante a guerra na Sérvia. A Turquia foi bastante elogiada por usar seus jatos F-16, que nós lhe havíamos fornecido, para bombardear a Sérvia - os mesmos aviões que usara contra a sua própria população até finalmente conseguir esmagar o "terror interno", como o chamavam. Como sempre, toda resistência inclui, de fato, terror. Isso foi verdade na Revolução norte-americana. Foi verdade em todos os casos que conheço. Assim como é verdade que aqueles que detêm o monopólio da violência sempre dizem que estão empenhados em contraterrorismo.

\section{A coalizão - incluindo Argélia, Rússia, China e Indonésia}

Isso é muito impressionante e diz respeito à coalizão sendo organizada para a guerra contra o terror. É muito interessante ver como a coalizão está sendo descrita. Vejamos a edição de hoje do Christian Science Monitor. É um bom jornal, um dos melhores jornais internacionais, com cobertura real do mundo. A matéria principal, a matéria de capa, é sobre os Estados Unidos: explica que antes as pessoas não gostavam dos Estados Unidos mas que agora estão começando a respeitá-lo, que estão todos muito felizes com a liderança dos Estados Unidos na guerra contra o terror. O exemplo principal - na verdade, o único exemplo sério, pois os outros são uma piada - é a Argélia. Descobri- 
mos que a Argélia está bastante entusiasmada com a guerra dos Estados Unidos contra o terror.

O autor do artigo é um especialista em África. Deve, pois, saber que a Argélia é um dos Estados terroristas mais perversos do mundo e vem lançando terror contra a sua própria população há anos. Durante um tempo, isso foi mantido em segredo. Mas finalmente tudo veio à tona na França, graças a dissidentes do exército argelino. Tudo foi amplamente divulgado lá e também na Inglaterra. Mas aqui sentimos orgulho porque um dos mais corruptos Estados terroristas do mundo está entusiasmado com a guerra dos Estados Unidos contra o terror - chegando inclusive a nos encorajar a liderar a guerra. Isso mostra o quanto estamos nos tornando populares.

Se examinarmos a coalizão que está sendo formada contra o terror, aprenderemos muitas outras coisas. Um dos principais membros da coalizão é a Rússia, que está mais do que eufórica em ter os Estados Unidos apoiando o morticínio da sua guerra terrorista na Chechênia - ao invés de às vezes criticá-lo discretamente. A China também está se juntando à coalizão com entusiasmo. Está felicíssima em obter apoio para as atrocidades que vem cometendo no oeste do país contra o que chama de secessionistas islâmicos. A Turquia, como já mencionei, está contentíssima com a guerra contra o terror. Todos esses países são especialistas nisso. Argélia e Indonésia estão satisfeitíssimas de terem ainda mais apoio dos Estados Unidos para as atrocidades sendo cometidas na província de Aceh e em outras regiões. Se percorrermos a lista, essa lista impressionante de Estados que se juntaram à coalizão contra o terror, verificaremos que há uma característica em comum: incluem-se certamente entre os principais Estados terroristas do mundo. Não é por acaso que estão sendo liderados pelo campeão mundial da modalidade.

\section{O que é terrorismo?}

Isso nos traz de volta à pergunta: O que é terrorismo? Até aqui pressupus que todos nós sabemos o que é. Pois bem, o que é? Existe uma resposta fácil para esta pergunta, uma definição oficial. Podemos encontrá-la na legislação norte-americana ou nos manuais do exército. Uma breve definição, extraída de um manual do exército norte-americano, diz que “terror é o uso premeditado da violência ou da ameaça de violência para atingir metas ideológicas políticas ou religiosas mediante intimidação, coerção ou instilação do medo". Isso é terrorismo. É uma definição mais do que equânime. Acho razoável aceitá-la. O problema é que não poderemos aceitá-la, pois dela decorrem toda a sorte de conseqüências erradas - por exemplo, todas as conseqüências que acabamos de examinar. Há hoje um grande esforço nas Nações Unidas para tentar elaborar um tratado abrangente sobre terrorismo. Quando Kofi Annan recebeu o prêmio Nobel, ele teria dito que nós deveríamos parar de desperdiçar tempo nisso e colocar mãos à obra. 
Só que há um problema. Se usarmos a definição oficial de terrorismo desse tratado abrangente, chegaremos aos resultados errados. Isso é inaceitável. Na realidade, é ainda pior que isso. Se examinarmos a definição de "guerra de baixa intensidade", que é a política oficial dos Estados Unidos, veremos que é uma paráfrase bastante próxima do que acabei de ler. Na realidade, "conflito de baixa intensidade" é apenas um outro nome para terrorismo. É por isso que, pelo que sei, todos os países designam de contraterrorismo quaisquer atos horrendos que estejam cometendo. Nós chamamos isso de contra-insurgência ou conflito de baixa intensidade. É um problema grave. Não podemos usar as definições em si. Temos de cuidadosamente encontrar uma definição que não traga no bojo todas as conseqüências erradas.

\section{Por que Estados Unidos e Israel votaram contra uma importante resolução condenando o terrorismo?}

Há ainda outros problemas. Alguns surgiram em dezembro de 1987, no auge da primeira guerra contra o terrorismo, quando o furor contra essa praga atingira o apogeu. A Assembléia Geral das Nações Unidas aprovara uma resolução bastante forte contra o terrorismo, condenando a praga em termos enérgicos e convocando todas as nações a combaterem-na de todas as formas possíveis. Foi aprovada por quase unanimidade.

Um país - Honduras - se absteve, houve dois votos contra, os de sempre - Estados Unidos e Israel. Por que Estados Unidos e Israel votaram contra essa importante resolução condenando o terrorismo nos termos mais veementes (na verdade, basicamente os mesmos termos que o governo Reagan vinha usando)?

Houve um motivo. Há um parágrafo nessa longa resolução que afirma que nenhuma cláusula do documento coíbe o direito de um povo em luta contra regimes racistas e colonialistas ou contra ocupação militar estrangeira de continuar a sua resistência com a ajuda de outrem - de outros Estados, Estados externos - na sua justa causa. Ora, nem os Estados Unidos nem Israel puderam aceitar isso. Na época, o principal motivo de não poderem aceitar isso era a África do Sul. A África do Sul era uma aliada, uma nação oficialmente designada como aliada. E havia uma força terrorista na África do Sul. Era chamado Congresso Nacional Africano, oficialmente designado uma força terrorista. A África do Sul, por sua vez, era uma aliada e nós certamente não poderíamos apoiar ações de um grupo terrorista que lutava contra um regime racista. Isso seria impensável.

Havia, é claro, outro motivo, a saber, os territórios ocupados por Israel há 35 anos. Com o apoio incondicional dos Estados Unidos impedindo uma resolução diplomática há 30 anos, o motivo permanece válido hoje. Por isso era inadmissível. $\mathrm{Na}$ época havia ainda mais um motivo. Israel estava ocupando o sul do Líbano e estava sendo combatido pelo que os Estados Unidos chama- 
vam de força terrorista, o Hizbollah. (Que na realidade logrou expulsar Israel do Líbano.) Não podemos permitir que ninguém lute contra uma ocupação militar quando se trata de uma ocupação que nós apoiamos. Portanto, Estados Unidos e Israel não tinham como não votar contra a resolução das Nações Unidas contra o terrorismo. E como mencionei antes, um voto contra dos Estados Unidos é essencialmente um veto.

Mas isso é só metade do caso. O veto norte-americano também suprimiu da história a resolução. Nada disso foi noticiado e nada disso sequer constou nos anais do terrorismo. Se examinarmos os trabalhos acadêmicos sobre terrorismo, não encontraremos nada do que acabo de mencionar. O motivo é que as "pessoas erradas" estão empunhando as armas. Precisamos aperfeiçoar as definições e a pesquisa acadêmica para chegar às conclusões "certas"; doutra forma, não haverá pesquisa acadêmica respeitável nem jornalismo honrado.

Esses são alguns dos problemas que estão estorvando a iniciativa de elaborar um tratado abrangente contra o terrorismo. Talvez devêssemos organizar uma conferência acadêmica, ou algo parecido, para tentar encontrar um meio de definir terrorismo que leve às respostas certas, não às incorretas. Isso não será fácil.

\section{Quais as origens dos crimes de 11 de setembro?}

Mas deixemos isso de lado e passemos para a quarta questão: Quais as origens dos crimes de 11 de setembro? Temos aqui de fazer uma distinção entre duas categorias que não devem ser embaralhadas. A primeira diz respeito aos agentes efetivos do crime. A outra refere-se a uma espécie de "reserva de solidariedade" - $\mathrm{e}$, às vezes, de apoio - que os eventos inspiraram até mesmo entre pessoas que se opõem claramente aos criminosos e suas ações. São duas coisas bem diferentes.

\section{Categovia 1: os prováveis perpetradoves}

Com relação aos perpetradores, a verdade é que, num certo sentido, a situação ainda não está clara. Os Estados Unidos não podem ou não querem fornecer qualquer tipo de prova ou comprovação significativa. Houve uma grande encenação dramática há uma ou duas semanas, quando Tony Blair foi incitado a tentar apresentar algo. Não sei ao certo qual foi o propósito daquilo. Talvez fazer parecer que os Estados Unidos estivessem retendo alguma prova secreta que não pudessem revelar. Ou talvez permitir que Tony Blair assumisse ares apropriadamente churchillianos ou algo assim.

Quaisquer que tenham sido os objetivos de relações públicas, Blair fez uma apresentação que em círculos sérios foi considerada tão absurda que praticamente não chegou a ser mencionada. The Wall Street Journal, por exemplo, um dos jornais mais sérios, publicou uma pequena matéria na página 12 , se não 
me engano, apontando que não havia muita prova e citando um alto funcionário do governo norte-americano que teria dito que não importava se havia ou não havia provas, pois eles iriam levar a coisa adiante de qualquer maneira. Por que se preocupar com provas?

Jornais mais ideológicos, como The New York Times, entre outros, publicaram grandes manchetes na primeira página. Mas a reação do The Wall Street Journal foi razoável e se examinarmos as ditas provas veremos por quê. Mesmo supondo que elas sejam legítimas, porém, é espantoso como são fracas. Acho que seria possível desencavar coisa melhor sem o serviço de inteligência [risos da platéia]. Pois tenham em mente que isso ocorreu semanas após a investigação mais intensa da história, com todos os serviços de inteligência do mundo ocidental trabalhando em tempo integral para trazer à tona alguma coisa. E tudo prima facie. Era uma demanda bastante forte antes mesmo de surgir alguma coisa. Mas acabou basicamente onde havia começado, com um caso prima facie. Todavia, suponhamos que seja verdade. Aceitemos isso que pareceu óbvio no primeiro dia e que ainda parece: que os verdadeiros perpetradores vieram de redes islâmicas radicais, aqui chamadas de fundamentalistas, da qual a rede de Osama bin Laden é inegavelmente uma parte importante. Se estavam de fato envolvidos ou não, ninguém sabe. E não importa muito.

\section{De onde vievam?}

Este é o contexto, essas redes. Pois bem, de onde elas vieram? Todos nós sabemos. E ninguém sabe melhor do que a CIA, pois foi a CIA que ajudou a organizá-las e que as alimentou por um longo tempo. Essas redes foram organizadas nos anos 80 pela própria CIA e suas comparsas em outros países: Paquistão, Grã-Bretanha, França, Arábia Saudita, Egito. A China esteve envolvida, talvez tenha se envolvido um pouco antes, em 1978. A idéia era assediar os russos, o inimigo comum. De acordo com Zbigniew Brzezinski, assessor de segurança nacional do presidente Carter, os Estados Unidos se envolveram em meados de 1979. (Só para acertar as datas, vamos nos lembrar que a Rússia invadiu o Afeganistão em dezembro de 1979.) De acordo com Brzezinski, o apoio norte-americano aos mujahedin que lutavam contra o governo começou seis meses antes. Brzezinski tem muito orgulho disso. Ele diz que nós atraímos os russos para uma "armadilha afegã" - são palavras suas - apoiando os mujahedin e fazendo os russos invadirem e cair na armadilha. Formamos assim um tremendo exército mercenário. Não um exército pequeno, mas um exército de, talvez, 100 mil homens, reunindo os melhores assassinos que puderam ser encontrados: os fanáticos islâmicos radicais do norte da África, da Arábia Saudita, de onde quer que fosse.

Eram muitas vezes chamados de afegãos, mas muitos deles, como Bin Laden, não eram afegãos. Foram trazidos de outras partes do mundo pela CIA e suas comparsas. Não sei se Brzezinski está falando a verdade. Talvez estivesse 
apenas se jactando. Ele aparentemente tem muito orgulho deste feito-mesmo conhecendo as consequiências. Mas talvez seja verdade. Saberemos um dia, se os documentos forem liberados. Seja como for, essa é a sua percepção. Não resta a menor dúvida de que em janeiro de 1980 os Estados Unidos estavam organizando os afegãos e preparando uma enorme força militar para causar o máximo de problemas para os russos. Seria perfeitamente legítimo para os afegãos lutarem contra a invasão russa. Mas a intervenção norte-americana não estava ajudando os afegãos. Na realidade, ajudou apenas a destruir o país. Enfim, os próprios afegãos acabaram forçando os russos a se retirar.

Nesse ínterim, as forças terroristas que a CIA estava organizando, armando e treinando buscavam desde o princípio pôr em prática o seu próprio programa. Não era segredo.

Um dos primeiros atos ocorreu em 1981, quando assassinaram o presidente do Egito, um dos mais entusiásticos de seus criadores. Em 1983, um homem-bomba suicida (que talvez estivesse, ou não, ligado a essas forças - tudo é bastante nebuloso, ninguém sabe) expulsou do Líbano os militares do exército norte-americano. As coisas continuaram assim. As forças terroristas tinham o seu próprio programa. Os Estados Unidos acharam ótimo poder mobilizá-las para lutarem por sua causa, mas as forças estavam avançando os seus próprios interesses. Foram bem claras a respeito. Depois de 1989, quando os russos já haviam se retirado, elas simplesmente começaram a agir em outros lugares. Têm lutado desde então na Chechênia, no oeste da China, na Bósnia, na Caxemira, no sudeste asiático, no norte da África, por todo o mundo.

\section{Eles estão nos dizendo o que pensam}

Eles estão nos dizendo o que pensam. Os Estados Unidos querem silenciar o único canal de televisão livre do mundo árabe porque está transmitindo a gama completa dos fatos, de Colin Powell a Osama bin Laden. Com essa atitude, estão se equiparando aos regimes repressivos do mundo árabe, que tentam calar essa TV. Mas se assistirmos esse canal, se pudermos ouvir o que Bin Laden diz, veremos que vale a pena. Além disso, eles apresentam muitas entrevistas, realizadas pelos principais repórteres do Ocidente, como Robert Fisk e outros, se preferirmos não ouvir a voz de Bin Laden. Mas ele vem falando com bastante consistência há tempos. Não é o único, mas talvez seja o mais eloqüente. Não só com consistência, mas também consoante com suas ações.

Por isso, temos todos os motivos para levá-los a sério. Seus inimigos primordiais são aqueles que chamam de "regimes autoritários brutais, corruptos e opressivos do mundo árabe". Quando dizem isso, obtêm uma grande ressonância na região. No entanto, eles também querem substituir esses regimes por governos mais incisivamente islâmicos. E é aí que perdem a simpatia das pessoas da região. Até esse momento, porém, estão todos com eles. Do ponto de 
vista de Osama bin Laden e outros, nem mesmo a Arábia Saudita é suficientemente islâmica para eles, embora seja talvez o Estado fundamentalista mais extremo do mundo, com exceção do Taliban (que é uma ramificação). É evidente que nesse ponto contam com pouquíssimo apoio. Mas aquém disso, têm um apoio tremendo.

Eles também querem defender os muçulmanos de outras regiões. Odeiam os russos como à peste, mas tão logo os russos deixaram o Afeganistão, pararam de realizar atos terroristas na Rússia, como vinham fazendo antes com o apoio da CIA - ataques dentro da Rússia, não apenas no Afeganistão. É verdade que avançaram para a Chechênia. Mas lá estão defendendo os muçulmanos de uma invasão russa. $\mathrm{O}$ mesmo acontece em todos os outros lugares que mencionei. Do ponto de vista deles, estão defendendo os muçulmanos dos infiéis. E são muito claros a respeito; é isso que eles têm feito.

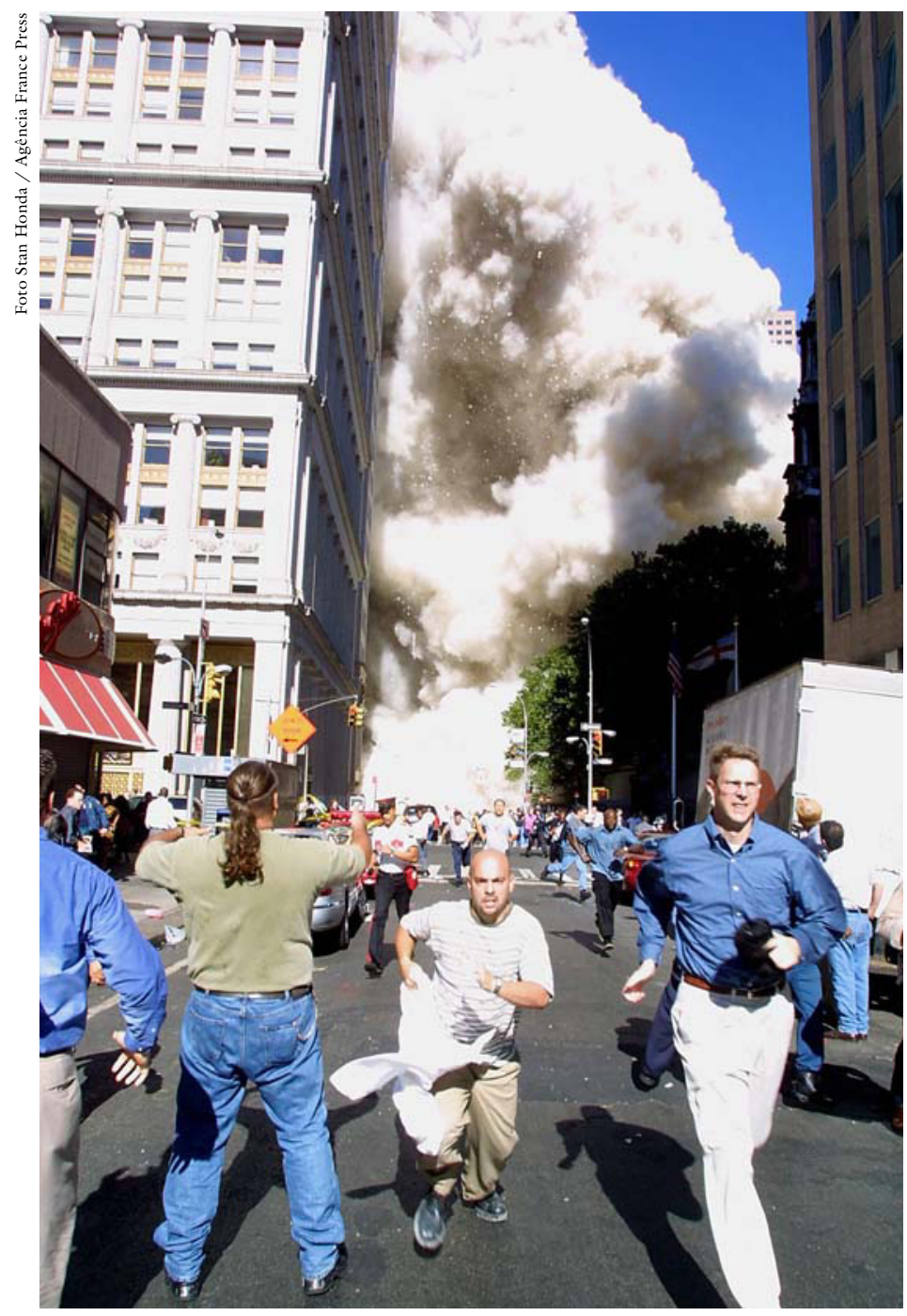

As duas torres do World Trade Center em Nova York desabam 


\section{Por que se voltaram contra os Estados Unidos?}

Mas por que eles se voltaram contra os Estados Unidos? Bem, isso está relacionado com o que chamam de "invasão norte-americana da Arábia Saudita”. Em 1990, os Estados Unidos montaram bases militares permanentes na Arábia Saudita - o que, do ponto de vista deles, é comparável à invasão russa do Afeganistão. Só que a Arábia Saudita é muito mais importante. É lá que ficam os lugares mais sagrados do Islã. Foi isso que fez as atividades desses grupos se voltarem contra os Estados Unidos. Vocês devem se lembrar que em 1993 eles tentaram explodir o World Trade Center.

Conseguiram realizar só uma parte do seu intento - que, aliás, era apenas parte de um plano maior. O objetivo era explodir o prédio das Nações Unidas, os túneis Holland e Lincoln e a sede do FBI. Acho que havia ainda outros alvos na lista. Uma das muitas pessoas que foram presas por este atentado foi um clérigo egípcio que havia viajado para os Estados Unidos, a despeito das objeções do Serviço de Imigração, graças à intervenção da CIA, que queria agraciar seus amigos. Alguns anos depois, ele tentava explodir o World Trade Center. Isso tem acontecido em toda a parte. Não vou percorrer a lista toda, mas é um quadro consistente, se vocês me entendem. Está tudo descrito em palavras. Está tudo revelado nas práticas de 20 anos. Não há motivo para não os levarmos a sério. Esta é a primeira categoria: os prováveis perpetradores.

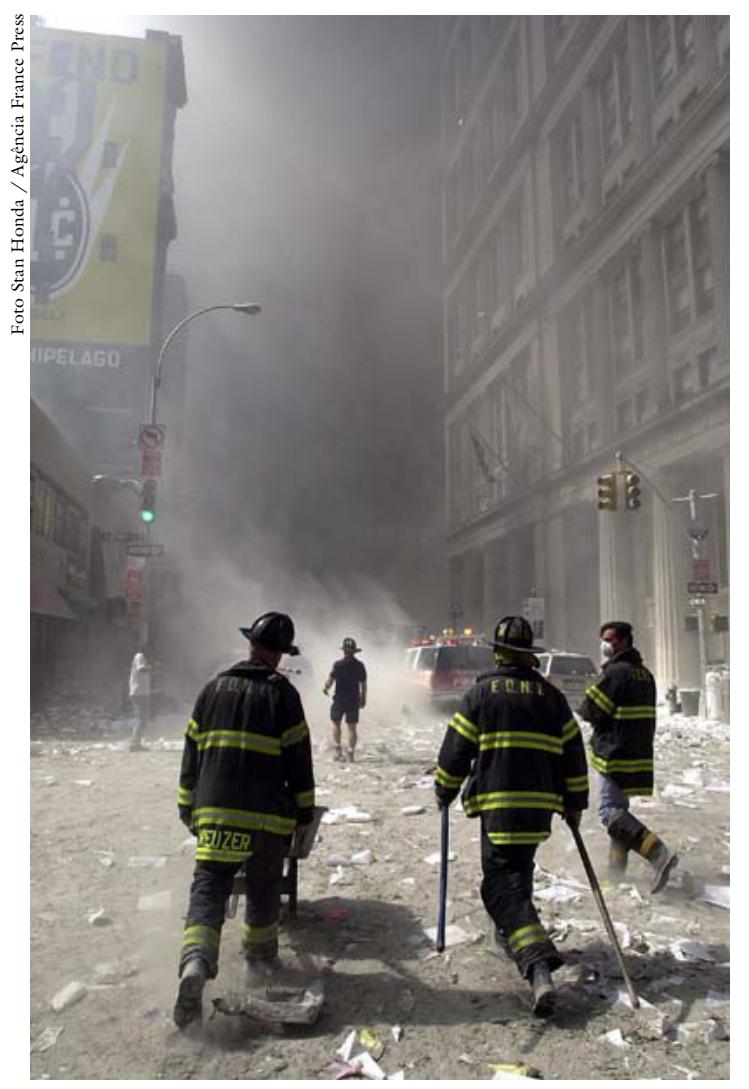

Os bombeiros (heróis na catástrofe) iniciam o trabalho nos escombros 


\section{Categoria 2: e quanto à reserva de apoio?}

Bem, não é difícil descobrir do que se trata. Uma das coisas boas que aconteceram desde 11 de setembro foi que uma parte da imprensa e uma parte do debate a respeito começaram a se abrir para algumas dessas outras perspectivas. A melhor delas, a meu ver, foi The Wall Street Journal, que desde os primeiros dias passou a publicar matérias sérias, reportagens investigativas sérias sobre os motivos pelos quais as pessoas da região, apesar de odiarem Bin Laden e abominarem tudo o que ele está fazendo, não obstante o apóiam de várias maneiras, e até chegam a considerá-lo a consciência do Islã, como um deles chegou a dizer.

Entretanto, The Wall Street Journal e outros não estão sondando a opinião pública; estão sondando a opinião de seus amigos - banqueiros, profissionais liberais, advogados internacionais, empresários com vínculos com os Estados Unidos, pessoas vestindo roupas norte-americanas de grife entrevistadas num restaurante McDonald's (que lá é um restaurante elegante).

São essas as pessoas que entrevistam, porque são as atitudes delas que eles querem desvendar. Suas atitudes são bem explícitas e bem claras, e em várias maneiras consoantes com a mensagem de Bin Laden e outros. Estão todas furiosas com os Estados Unidos por apoiarem regimes autoritários e brutais; por intervirem para impedir qualquer movimento rumo à democracia; por agirem para frustrar o desenvolvimento econômico; pelas diretrizes que devastaram a sociedade civil do Iraque ao mesmo tempo em que fortaleceram Saddam Hussein. E essas pessoas se lembram - ainda que nós prefiramos não fazê-lo que os Estados Unidos e a Grã-Bretanha apoiaram Saddam Hussein, mesmo enquanto ele cometia as piores atrocidades - entre elas, o extermínio dos curdos com armas químicas. Bin Laden sempre traz isso à baila. Elas sabem disso, mesmo que nós não saibamos.

Para não falar, é claro, no apoio norte-americano à ocupação militar israelense, que é implacável, brutal e já entrou no seu $35^{\circ}$ ano. Os Estados Unidos forneceram, e continuam fornecendo, a esmagadora maioria da ajuda econômica, militar e diplomática dessa ocupação. Elas sabem disso, e não gostam. Especialmente quando comparam essa atitude com a política norte-americana para o Iraque, para a sociedade civil iraquiana, que está sendo destruída. Basicamente, esses são os motivos. E quando Bin Laden apresenta esses motivos, as pessoas sabem reconhecê-los e oferecem seu apoio.

Mas este não é o modo como as pessoas aqui pensam a respeito. Ou pelo menos não é como opinião liberal instruída raciocina, que prefere a linha adotada por toda a mídia e, em particular, pela esquerda liberal. Não investiguei a fundo, mas acho que, no geral, as opiniões de direita têm sido mais honestas. Basta olharmos, digamos, The New York Times. No primeiro editorial escrito por 
Ronald Steel, um intelectual liberal de esquerda sério, ele pergunta: "Por que eles nos odeiam?" (Isso no mesmo dia, se não me engano, em que The Wall Street Journal publicava uma pesquisa sobre os motivos de eles nos odiarem.) Steel diz o seguinte: "Eles nos odeiam porque nós representamos uma nova ordem mundial de capitalismo, individualismo, secularismo e democracia que deveria ser a norma em toda a parte. É por isso que eles nos odeiam.”

No mesmo dia, The Wall Street Journal pesquisava as opiniões de banqueiros, profissionais liberais e advogados internacionais, que diziam: "Vejam, nós odiamos vocês porque estão bloqueando a democracia, impedindo o desenvolvimento econômico, apoiando regimes brutais, regimes terroristas, e cometendo uma série de coisas horríveis na região. "Alguns dias depois, Anthony Lewis, bem mais à esquerda, explicou que o terrorista busca apenas "niilismo apocalíptico", nada mais - não importa o que façamos. Segundo ele, a única consequiência de nossas ações que poderia ser nociva seria tornar mais difícil para os árabes se unirem ao esforço antiterrorismo da coalizão. Afora isso, tudo o que fizermos será irrelevante.

Bem, essa atitude tem a vantagem de ser reconfortante. Faz-nos sentir bem acerca de nós mesmos, como somos maravilhosos. Permite-nos evadir as consequiências de nossa ações. Mas também tem algumas falhas. A primeira é que contraria tudo o que sabemos a respeito da situação. Outra é que constitui uma maneira perfeita de assegurar a escalada do ciclo de violência. Se quisermos viver com a cabeça enfiada na areia e fingir que eles nos odeiam porque são contra a globalização... Que é por isso que mataram Sadat 20 anos atrás, e combateram os russos, e tentaram explodir o World Trade Center em 1993... Se quisermos acreditar nisso, não deixa de ser reconfortante. Mas é uma ótima maneira de assegurar a proliferação da violência. Uma violência tribal: você fez algo contra mim, eu farei algo pior contra você. Não me importa quais são os motivos. Vamos continuar agindo assim. Esta é a maneira de agir. Ou pelo menos é o que tem afirmado a opinião liberal de esquerda.

\section{Quais são as opções políticas?}

Bem, há várias. Desde o início, uma opção política limitada seria seguir o conselho de radicais realmente extremados como o papa [risos da platéia]. O Vaticano reagiu imediatamente dizendo: "Olhem, este foi um crime terrorista terrível. Como qualquer crime, devemos buscar os perpetradores, processá-los e julgá-los. E não sair matando civis inocentes". É como se alguém assaltasse a minha casa e eu achasse que o ladrão provavelmente ainda estaria na vizinhança, do outro lado da rua, e eu fosse até lá com um rifle automático e matasse todos os habitantes do bairro. Não é assim que se lida com o crime - seja um crime menor como este, seja um crime grandioso como a guerra terrorista dos Estados Unidos contra a Nicarágua, sejam crimes ainda piores ou intermediários. 
Há inúmeros precedentes. Na realidade, já mencionei um precedente, a Nicarágua, uma nação fundada no direito e respeitadora das leis. É por isso que, presumivelmente, tivemos de destruí-la, por seguir os princípios certos. Pois bem, é claro que isso não a ajudou em nada, pois a Nicarágua estava enfrentando uma potência que não permitia que procedimentos legítimos fossem adotados. No entanto, caso os Estados Unidos tentassem adotar os procedimentos corretos, ninguém iria nos impedir. Na realidade, todos aplaudiriam.

\section{Bombas do Exército Republicano Irlandês em Londres}

Quando o Exército Republicano Irlandês lançou bombas em Londres - um ato extremamente grave - uma reação possível da Grã-Bretanha (exceto pelo fato de ser inexeqüível, mas deixemos isso de lado) teria sido destruir Boston, que foi de onde se originou grande parte do financiamento do IRA. E também, é claro, aniquilar a região oeste de Belfast. Pois bem, afora a questão da inexeqüibilidade, teria sido uma estupidez criminosa. A maneira de lidar com a situação foi basicamente como eles agiram: encontrar os perpetradores, levá-los a julgamento e buscar os motivos. Porque essas ações não surgem do nada; elas sempre surgem de algo. Seja um crime nas ruas, seja um monstruoso crime terrorista, seja o que for. Sempre há motivos. E, via de regra, se examinarmos os motivos, veremos que alguns são legítimos e devem ser considerados. Não importa qual tenha sido o crime, os motivos devem ser considerados porque são legítimos. Essa é a maneira de lidar com tais situações. Há muitos outros exemplos semelhantes.

Todavia, também aqui surgem certos problemas. Um deles é que os Estados Unidos não reconhecem a jurisdição de instituições internacionais. Não podem, portanto, recorrer a elas. Os Estados Unidos rejeitaram a jurisdição da Corte Mundial. Recusaram-se a ratificar o Tribunal Internacional de Justiça, mas o país é poderoso o bastante para instituir um novo tribunal, se quiser, de modo que tudo isso não o impediria.

O problema com esse tipo de tribunal é que precisamos apresentar provas. Quando se recorre a uma corte de justiça, é preciso apresentar algum tipo de prova. Não basta Tony Blair fazendo um discurso na televisão. E isso é muito difícil. Pode ser impossível encontrar provas.

\section{Resistência sem líderes}

É possível que todas as pessoas que cometeram os crimes do dia 11 tenham se matado. Ninguém sabe disso melhor do que a CIA. Essas redes são descentralizadas, não-hierárquicas. Seguem um princípio chamado "resistência sem líderes". É o mesmo princípio elaborado pelos terroristas da direita cristã nos Estados Unidos. Resistência sem líderes. Montam-se pequenos grupos para agir. Esses grupos não se comunicam nem entre si nem com ninguém. Têm em comum apenas um conjunto geral de pressupostos e então simplesmente par- 
tem para a ação. Na verdade, pessoas envolvidas com movimentos pacifistas conhecem bem o esquema. Nós o chamávamos "grupos de afinidade". Partese do princípio de que um grupo oficial a que se pertença será sempre infiltrado pelo FBI se algo sério acontecer. Por isso, nada será feito ou decidido em reuniões. Reúnem-se algumas pessoas conhecidas e confiáveis, e monta-se um grupo de afinidade, que é impossível de ser infiltrado. Este é um dos motivos pelos quais o FBI nunca conseguiu descobrir o que acontece nos movimentos populares.

Com os outros órgãos de inteligência acontece a mesma coisa: eles não conseguem penetrar os grupos de afinidade, os grupos de resistência sem líderes. É praticamente impossível penetrar uma rede descentralizada.

Portanto, é bem possível que eles simplesmente não saibam. Quando Osama bin Laden afirma que não esteve envolvido, é perfeitamente possível. $\mathrm{Na}$ verdade, o difícil é imaginar como alguém morando numa caverna do Afeganistão, sem dispor sequer de um rádio ou telefone, poderia ter planejado uma operação tão sofisticada. Tudo indica que ela nasceu desse conjunto geral de pressupostos em comum com outros grupos terroristas de resistência sem líderes. E isso significa que será extremamente difícil achar alguma prova.

\section{Estabelecendo credibilidade}

Os Estados Unidos não querem apresentar provas porque querem ser capazes de agir sem provas. Este é um aspecto crucial da reação. Reparem que os Estados Unidos não pediram autorização ao Conselho de Segurança, que provavelmente teria sido concedida dessa vez (não por motivos nobres, diga-se de passagem, mas porque os demais membros do Conselho de Segurança também são Estados terroristas). Ficaram felizes em participar de uma coalizão contra o que chamam de terror, ou melhor, de apoio ao seu próprio terror. A Rússia não iria vetar; eles adoram esse tipo de coisa. De modo que os Estados Unidos provavelmente teriam obtido autorização do Conselho de Segurança. Mas não a quiseram. E não a quiseram porque seguem um princípio de longa data - um princípio que não surgiu com George Bush, mas já estava explícito no governo Clinton, articulado há muito tempo, a saber, o direito de agir unilateralmente.

Nós não queremos autorização internacional porque queremos agir unilateralmente. Não estamos interessados em provas. Não estamos interessados em negociação. Não estamos interessados em tratados. Não há ninguém mais forte do que nós. Somos o facínora mais durão do bairro. Fazemos o que queremos. Autorização é uma coisa ruim e, portanto, deve ser evitada. Temos até um nome para isso na literatura técnica: chama-se estabelecer credibilidade. É preciso estabelecer credibilidade. Este é um fator importante em muitas diretrizes. Foi o motivo oficial dado para a guerra nos Balcãs, o motivo mais plausível. 
Se quiserem saber o que significa credibilidade, perguntem a qualquer capo da máfia. Ele saberá explicar o que quer dizer credibilidade. É a mesma coisa em assuntos internacionais, só que a questão é discutida nas universidades com palavras rebuscadas, mas o princípio é basicamente o mesmo. E faz sentido. E geralmente funciona. O principal historiador que escreveu a respeito nos últimos anos foi Charles Tilly, num livro intitulado Coerção, capital e os Estados europeus. Tilly mostrou que a violência foi o princípio motriz da Europa durante centenas de anos e o motivo foi que a violência funciona. Isso é bastante razoável. A violência quase sempre funciona. Quando se tem um predomínio avassalador da violência e uma cultura subjacente de violência, faz sentido seguir o princípio da violência.

Bem, esses são todos problemas que surgem quando se busca seguir caminhos legítimos. A verdade é que se tentássemos andar dentro da lei, abriríamos algumas portas muito perigosas. Os Estados Unidos estão exigindo que o Taliban lhes entregue Osama bin Laden. O Taliban está reagindo de uma maneira que o Ocidente considera totalmente absurda e bizarra, a saber, eles estão dizendo: "Ok, mas antes mostre-nos alguma prova". No Ocidente, isso é considerado grotesco, um indício da sua criminalidade. Como podem exigir provas? Afinal, se nos pedissem para entregar alguém, faríamos isso sem pestanejar amanhã mesmo. Não pediríamos prova alguma. [risos da platéia]

\section{Haiti}

É fácil comprovar isso. Não precisamos inventar caso algum. O Haiti, por exemplo, há vários anos vem solicitando que os Estados Unidos extraditem Emmanuel Constant. Este homem é um grande assassino. Foi uma das principais figuras no massacre de quatro a cinco mil pessoas em meados dos anos 90, sob a junta militar - que, por falar nisso, contava com o apoio nada tácito dos governos Bush e Clinton. Seja como for, Constant é um assassino. Os haitianos têm provas de sobra. Nenhum problema quanto a isso. Constant já foi julgado e condenado no Haiti e os haitianos estão pedindo que os Estados Unidos o entreguem. Bem, façam sua lição de casa. Tentem descobrir quanta discussão houve a respeito. Na verdade, o Haiti refez o seu pedido há cerca de duas semanas. Isso sequer foi mencionado. Por que deveríamos entregar um assassino condenado, responsável pela morte de quatro a cinco mil pessoas? O fato é que, se o entregarmos, quem sabe o que ele poderá dizer? Talvez diga que foi financiado e ajudado pela CIA - o que é provavelmente verdade. Nós não queremos abrir essa porta. E ele não é o único.

\section{Costa Rica}

A Costa Rica, que preza a democracia, vem há 15 anos tentando que os Estados Unidos lhe entreguem um certo John Hull, um latifundiário norte-americano com vastas propriedades na Costa Rica, a quem acusam de crimes terro- 
ristas. Dizem os costarriquenhos, com provas em abundância, que Hull usava as suas terras como base para a guerra dos Estados Unidos contra a Nicarágua - o que não é uma conclusão controversa, lembrem-se. Como a Corte Mundial e o Conselho de Segurança afiançaram o pedido, vêm tentando fazer com que os Estados Unidos o entreguem. Alguém ouviu falar disso? Creio que não.

Os costarriquenhos chegaram a confiscar as terras de outro latifundiário norte-americano, John Hamilton. Ofereceram indenização e pagaram a desapropriação. Os Estados Unidos recusaram. As terras de Hamilton, que também eram usadas como base para os ataques dos Estados Unidos contra a Nicarágua, foram transformadas num parque nacional. A Costa Rica foi punida por isso, foi punida com suspensão de ajuda. Nós não aceitamos esse tipo de insubordinação de nossos aliados. Eu poderia prosseguir. O fato é que se abrirmos as portas para perguntas sobre extradição, a questão pode tomar rumos bastante desagradáveis. Logo, isso não pode ser feito.

\section{Reações no Afeganistão}

E quanto às reações no Afeganistão? A proposta inicial, a retórica inicial envolvia um ataque maciço que mataria um grande número de pessoas, para não falar em ataques a outros países na região. Sabiamente, o governo Bush recuou. Foi informado por todos os líderes estrangeiros, pela OTAN, por todo tipo de especialista, imagino, por nossos próprios órgãos de inteligência, que esta seria a coisa mais estúpida que poderia fazer. Seria o equivalente a abrir agências de recrutamento para Bin Laden em toda a região. É exatamente isso o que ele quer. E seria extremamente danoso aos nossos próprios interesses. Portanto, resolveram reconsiderar. Mas estão voltando-se agora para o que descrevi há pouco como uma espécie de genocídio silencioso. Trata-se de... bem, eu já disse o que penso a respeito. Acho que nada mais precisa ser acrescentado. É só fazer as contas.

Uma proposta sensata que começa a ser considerada (uma proposta que sempre foi sensata mas só agora está sendo levantada) foi apresentada por afegãos expatriados e supostos líderes tribais internos: que haja uma iniciativa das $\mathrm{Na-}$ ções Unidas e os russos e os norte-americanos sejam mantidos totalmente fora da questão. Estes são os dois países que praticamente destruíram o Afeganistão nos últimos 20 anos. É justo que fiquem de fora. Deveriam mesmo pagar enormes reparações. Esta seria a sua única função. Uma iniciativa da ONU que reunisse todos os elementos dentro do Afeganistão e tentasse construir algo a partir dos destroços. É concebível que possa funcionar, se houver bastante apoio e nenhuma interferência. Se os Estados Unidos insistirem em dirigir o espetáculo, podemos desistir desde já. Temos uma longa história nesse ramo.

Reparem no nome que foi dado a esta operação. Lembram-se que a princípio iria ser uma Cruzada? Eles recuaram porque o pessoal de relações públi- 
cas disse que não iria dar muito certo [risos da platéia]. Escolheram então Justiça Infinita, mas o pessoal de relações públicas reclamou: "Esperem um pouco, vocês estão soando como uma divindade. Isso não vai funcionar". $\mathrm{O}$ nome então foi mudado para Enduring Freedom, ou Liberdade Duradoura. Nós sabemos o que isso significa. Felizmente, ninguém ainda apontou que existe uma ambigüidade aqui. Endure, além de "perdurar", também significa "sofrer resignadamente" [risos da platéia]. E, por certo, há muitas pessoas pelo mundo que sofreram resignadamente aquilo que chamamos de liberdade. Ainda bem que temos uma classe instruída, muito bem comportada, de modo que ninguém ainda apontou essa ambigüidade. Se o fizerem, teremos mais um problema para resolver.

Se conseguirmos nos conter apenas o suficiente para que algum órgão mais ou menos independente possa assumir a liderança - talvez a ONU, talvez alguma ONG fidedigna - talvez seja possível reconstruir algo a partir dos escombros. Com nossa ajuda, é claro; nós devemos isso a eles. Talvez então conseguíssemos algum resultado. Mas há outros problemas.

\section{Uma maneiva fácil de redusir o nivel de terror}

Nós certamente queremos reduzir o nível de terror, não aumentá-lo. Existe uma maneira fácil de realizar isso e que, por isso mesmo, nunca chega a ser discutida. A saber, parem de participar do terror. Bastaria isso para automaticamente reduzir em muito o nível de terror. Mas não se pode discutir isso. Esta seria uma maneira fácil de reduzir o nível de terror.

Além disso, deveríamos repensar o tipo de política que nos leva a organizar e a treinar exércitos terroristas - e o Afeganistão não é o único caso. Essas diretrizes têm efeitos. Estamos vendo alguns desses efeitos agora. Onze de setembro foi um deles. Temos de repensar isso.

Temos também de repensar as diretrizes que estão criando reservas de apoio contra nós. É exatamente isso que os banqueiros, advogados, entre outros, estão dizendo em lugares como a Arábia Saudita. Nas ruas, o clamor é muito mais amargo, como podemos imaginar. Isso é possível. Afinal, essas diretrizes não estão esculpidas em pedra.

E há também oportunidades. Tem sido difícil achar muitos raios de luz nas últimas semanas, mas um deles é que houve uma abertura maior. Muitas questões estão sendo abertas para discussão, mesmos nos círculos da elite, e certamente entre o público em geral - algo que não havia há duas ou três semanas. Chega a ser comovente. Quero dizer, se até um jornal como o USA Today consegue publicar uma matéria excelente, um artigo sério, sobre a vida na faixa de Gaza, é porque houve uma mudança. As coisas que mencionei sobre The Wall Street Journal também indicam uma mudança. 
Entre o público em geral, acho que há mais abertura e boa vontade para pensar sobre coisas que estavam escondidas sob o tapete. Essas são oportunidades e devem ser aproveitadas, pelo menos por aqueles que concordam com a meta de reduzir o nível de violência e terror, incluindo as ameaças potenciais extremamente severas, que poderão fazer com que até 11 de setembro pareça insignificante. Obrigado.

Noam Chomsky, lingüista e ativista político, é pesquisador do Massachusetts Institute of Technology (MIT), EUA. É autor, entre outros, de 11 de Setembro (Bertrand Brasil, 2001). Em 1955, aos 27 anos, recebeu seu PhD em Lingüística da Universidade da Pennsylvania. Aos 32 anos tornou-se professor-titular do MIT. Revolucionou a lingüística nos anos $60 \mathrm{com}$ sua teoria sobre a gramática generativa. Entre seus trabalhos fundamentais sobre o tema estão Aspectos da teoria da sintaxe e Linguagem e mente. Em 1969, com o livro O poder americano e os novos mandarins, começou sua trajetória como ativista dos direitos civis e seu combate contra a intervenção dos EUA no Vietnã. Publicou cerca de 23 livros sobre política internacional e questões internas dos EUA. Este é o segundo trabalho que o autor publica em ESTUDOS AVANÇADOS. O primeiro, Consentimento sem consentimento: a teoria e a prática da democracia, foi publicado em 1997 na edição número 29. O poder e a atuação dos meios de comunicação também têm sido objeto de sua análise crítica. É doutor honoris causa das Universidades de Chicago, Cambridge, Pennsylvania e Londres, entre outras.

Tradução por Carlos Afonso Malferrari. O original em inglês - The New War Against Terror - encontra-se à disposição do leitor no IEA-USP para eventual consulta. 